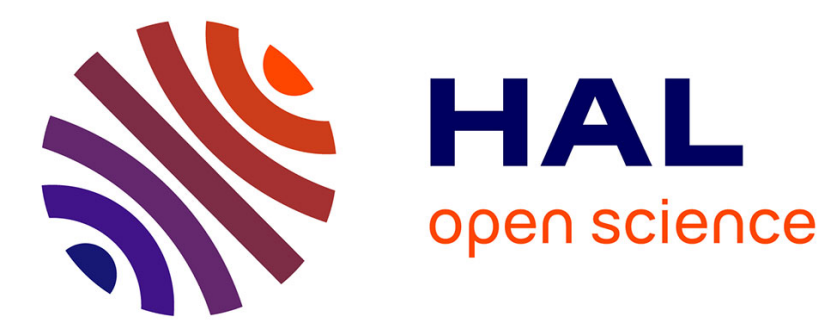

\title{
Hybrids and biohybrids as green materials for a blue planet
}

Leticia Carro, Elodie Hablot, Thibaud Coradin

\section{To cite this version:}

Leticia Carro, Elodie Hablot, Thibaud Coradin. Hybrids and biohybrids as green materials for a blue planet. Journal of Sol-Gel Science and Technology, 2014, 70 (2), pp.263-271. 10.1007/s10971-0133153-z . hal-01137513

\section{HAL Id: hal-01137513 https://hal.sorbonne-universite.fr/hal-01137513}

Submitted on 30 Mar 2015

HAL is a multi-disciplinary open access archive for the deposit and dissemination of scientific research documents, whether they are published or not. The documents may come from teaching and research institutions in France or abroad, or from public or private research centers.
L'archive ouverte pluridisciplinaire HAL, est destinée au dépôt et à la diffusion de documents scientifiques de niveau recherche, publiés ou non, émanant des établissements d'enseignement et de recherche français ou étrangers, des laboratoires publics ou privés. 


\title{
Hybrids and biohybrids as green materials for a blue planet
}

\author{
Leticia Carro, ${ }^{\mathrm{a}, \mathrm{b}}$ Elodie Hablot, ${ }^{\mathrm{c}}$ Thibaud Coradinn ${ }^{\mathrm{a},{ }^{*}}$
}

${ }^{a}$ UPMC Univ Paris 06; CNRS, Chimie de la Matière Condensée de Paris, Collège de France, 11, place Marcelin Berthelot, 75231 Paris cedex 05, France

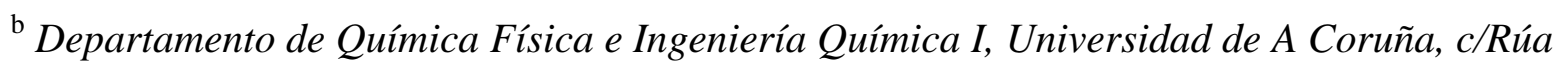
da Fraga 10, 15008 A Coruña, Spain

${ }^{\mathrm{c}}$ Michigan State Univ, Dept Chemical Engineering \& Materials Science, East Lansing, MI 48910 USA

* corresponding author: E-mail:thibaud.coradin@upmc.fr; tel: +33144271528; fax: $+33144271443$ 


\begin{abstract}
There is an urgency to identify novel technological answers to the decreasing availability of important resources together with increasing accumulation of pollution. Among the many ways materials science can contribute to these issues, the enhanced use of renewable resources, the optimal production of alternative energies and the improved monitoring/cleaning of contaminated environments can be identified as area where the sol-gel technology has, and will have, a major role to play. In this short review, we more specifically illustrate recent developments in biohybrid chemistry applied to bioplastics, biofuel cells, biosensors and bioremediation.
\end{abstract}

Keywords: bio-hybrids; encapsulation; bioplastics; biofuel cells; biosensors; bioremediation 


\section{Introduction}

« The Earth is blue like an orange » wrote the french poet Paul Eluard in 1929. Almost one century later, our planet is starting to be covered with shades of gray. Two main threats are well-identified, greenhouse gas effect and environmental pollution, with their cortege of deleterious impacts on climate, biodiversity, human health... Official estimations indicate that these dangers are mainly of anthropogenic origin, and mostly related to energy production [1]. These activities currently consume for most part non-renewable resources, of both organic and inorganic nature.

As an answer to the predicted shortage of fossil and mineral stocks, an acceptable short-term solution is to decrease our resource consumption rate by developing more energy/atom-effective technologies and improving waste management/recycling. However, in a longer-term perspective, there is a clear need to identify substitution strategies based either on virtually unlimited (sunlight, wind, seas oceans) or so-called renewable resources (mainly of vegetal origin). Indeed, doubts can be raised about the possibility for nearly 7 billion human beings to live without impacting negatively on the atmo- and biosphere. This is wellillustrated by the issues that are currently raised by crop-based biofuel production [2].

The possible role of the sol-gel processes in contributing to a more eco-responsible form of material synthesis following the principles of Green Chemistry has been recently reviewed [3]. The application of soft chemistry routes to the preparation of inorganic/hybrid devices for energy production or storage is also commonly described [4]. The importance of the sol-gel technology for pollution assessment and remediation has been less explored [5].

In this short review, we would like to present some recent achievements in these three areas, i.e. green materials, energy and environmental monitoring/remediation, that involve the 
sol-gel technology, especially focusing on biohybrids that associate natural systems, being biomolecules or whole cells, with inorganic materials and suggest some perspectives in these area.

\section{Sol-gel based bioplastics}

Polymers associated with sol-gel materials are of great interest in many applications [6,7]. Replacing conventional polymers by bio-based and biodegradable polymers would add to these materials the proposition of a reduced material carbon footprint and minimize our dependence on fossil/petro resources [8,9]. Biodegradable polymers issued from plants that have been associated with sol-gel materials include polysaccharides, proteins and vegetable oils [10].

In particular, many polysaccharides, such as pectin [11], xanthan gum [12], carageenan [13], guar gum [14] and alginic acid [15] have been considered for the synthesis of hybrid composites and nanocomposites to be used in biotechnological, biomedical and environmental applications. Cellulose- and chitin/chitosan-based biohybrids associated with silica are described in more details afterwards to illustrate the diversity of strategies and materials that have been reported in this area.

\subsection{Cellulose and cellulose derivatives}

The preparation of $\mathrm{SiO}_{2} /$ cellulose nanocomposites has been reported as displaying promising properties for different potential applications. These nanocomposites are prepared either by deposition of morphologically well-defined $\mathrm{SiO}_{2}$ nanoparticles at the fiber surface via polyelectrolytes assembly or via the synthesis of $\mathrm{SiO}_{2}$ nanoparticles using tetraethoxysilane (TEOS) hydrolysis in the presence of cellulose fibres [16]. Both methodologies induced a significant decrease in the water uptake capacity of cellulose fibres. 
Silica-modified cellulosic aerogels have also been prepared [17]. They consist of two interpenetrating networks of cellulose and silica, prepared from shaped cellulose solutions by (1) regenerating (reprecipitating) cellulose with ethanol, (2) subjecting the obtained shaped alcogels to sol-gel condensation with TEOS as the principal network-forming compound, and (3) drying the reinforced cellulose bodies with supercritical carbon dioxide. An open-porous network structure was obtained when silicification was performed under mild acidic conditions.

Bacterial cellulose (BC) hydrated membranes also present advantages for the preparation of new organic-inorganic hybrids due to its nanometer-scale reticulated structure [18-21]. BC-silica hybrids were prepared from BC membranes and TEOS in neutral pH conditions at room temperature. The resulting water-free translucent membranes exhibited improved mechanical properties and thermal and UV resistance [18,21]. Homogeneous membranes were obtained containing up to $66 \mathrm{wt} \%$ of silica spheres, $20-30 \mathrm{~nm}$ diameter, that were clearly attached to cellulose microfibrils (Fig. 1) [20]. Cellulose derivatives, such as cellulose acetate (CA) and carboxymethyl cellulose (CMC) were also associated with TEOS or silicates to obtain nanocomposites (Fig. 2) [22,23]. Of particular interest is the demonstration that the biodegradation of $\mathrm{CA} / \mathrm{SiO}_{2}$ membranes by Thricoderma harzianum fungi was not modified by the presence of the inorganic phase [22].

Direct modification of cotton fibers by deposition of $\mathrm{SiO}_{2} / \mathrm{TiO}_{2}$ multilayer films for outdoor applications also illustrate the versatility of the sol-gel based mineralization of natural materials [24]. In a first step, $\mathrm{SiO}_{2}$ particles were deposited on the surface of the cotton fibers using hydrolyzed TEOS. This first layer allows the protection of the fibers against photocatalytic decomposition by the second layer of $\mathrm{TiO}_{2}$ nanoparticles deposited using relatively mild temperature conditions $\left(100^{\circ} \mathrm{C}\right)$ by a sol-gel method. This method led to dense and uniform multilayer films. 


\subsection{Chitin and chitosan}

Chitin and chitosan have been widely investigated in the preparation of new hybrids materials via sol-gel process. As an example, a silica network was obtained by controlled hydrolysis of tetraethyl orthosilicate using deacetylated chitin as an organic counterpart [25]. The resulting polymer hybrids were homogeneous, transparent, film-forming glassy materials that can be obtained in a wide composition range. Similar systems were prepared through a sol-gel process starting from alkoxysilane and chitosan [26]. Further functionalization was performed through in situ hydrolysis-condensation reaction of methyltrimethoxysilane (MTMS) and vinyltrimethoxysilane (VTMS) in the reaction medium, leading to transparent and hydrophobic silica-chitosan hybrids that can find application in the optics industry. Membranes were also prepared by in situ crosslinking of chitosan and formation of chitosansilica hybrid membranes with $\gamma$-glycidoxypropyltrimethoxysilane as a crosslinking agent [27]. The formed chitosan-silica hybrid materials exhibited improved thermal stability and low degree of swelling in water.

Porous chitosan/silica hybrids microspheres were prepared by impregnation of preformed polysaccharide beads with silica precursors, and considered for use in heterogeneous catalysis [28]. More recently, chitosan-silica hybrid microspheres were obtained in a one-step process using a simple microfluidic method [29]. Bovine serum albumin was chemically grafted on the obtained microspheres and the presence of silica led to an enhancement of both mechanical stability and protein loading capacity of the microspheres.

One key advantage of these approaches is that non-gelling polymers can be obtained in a gel form by generating silica in situ via sol-gel processing [30]. This can be done by using a silica precursor, tetrakis(2-hydroxyethyl)orthosilicate (THEOS), that is fully water- 
soluble and compatible with the biopolymer. The gelation is caused by mineralization of carbohydrate macromolecules, which strengthen them and allow their cross-linking [31,32].

Biohybrid chitosan- $\mathrm{SiO}_{2}$ materials have been described for many applications, including biosensors [33,34] and sorbents [35,36]. Chitosan-silica hybrid membranes for bone repair were also described and evaluated in vitro [37-39]. Recently, it was possible to obtain hybrid nanofibers by electrospinning chitosan, polyethylene oxide with tetraethoxysilane and 3-glycidyloxypropyltriethoxysilane as silica precursors, exhibiting promising properties for guided bone generation [40].

\section{Bio-hybrid materials for energy}

In the field of eneregy, sol-gel routes to oxides as well as to hybrid materials allow to control the nanostructure of the material and/or to develop efficient interfaces. For lithium batteries, nanostructured systems using $\mathrm{TiO}_{2} / \mathrm{LiCoO}_{2}$ electrodes have been studied [41]. Mesoporous forms of these materials showed improved properties thanks to short lithium/electrons distance within the pore walls. Mesoporous materials may also be useful for capacitors design [42], as well as in photovoltaic systems, for instance by confining conjugated polymers within the mesoporosity of photoactive metal oxides, such as $\mathrm{TiO}_{2}$ [43]

The design of fuel cells is another area where the sol-gel technology is of particular interest. For instance, it allows the elaboration of nanostructured ceramic thin layers for high temperature solid oxide fuel cells (SOFC) design [44]. In the field of proton exchange membrane fuel cells (PEMFC), working at low temperature, nanocomposite, mesoporous and hybrid materials have been studied [45]. One particularly interesting approach is the use of ionic liquids as solvents to address the requirement for high humidity conditions, as demonstrated for phosphonated silica particles dispersed in a styrene-acrylonitrile resin in the presence of 1-ethyl-3-methyl- imidazolium-bis (trifluoromethanesulfonyl) imide [46]. 
Biofuel cells, that use a biological activity as a source of energy, also constitutes an interesting area to which sol-gel chemistry can contribute [47]. Indeed, from the pioneer works of Avnir [48] and Carturan [49], the possibility to immobilize enzyme and living cells inside silica gels while preserving, if not enhancing, their biological activity has been largely demonstrated [50,51]. Indeed, as bioelectrodes are targeted, it is important that the sol-gel matrix exhibit electronic conduction properties. However, silica is a very poor electronic conductor. This issue has been addressed earlier for the design of enzymatic electrochemical devices, via the incorporation of carbon particles and/or conductive polymers [52]. The additional use of mediators allowing the transfer of the electron from the enzyme to the material has also been described, leading to complex electrodes with high performances [53]. On this basis, silica gels incorporating carbon nanotubes (CNT) or graphene were found suitable for current generation based on the enzymatic glucose conversion into oxygen $[54,55]$.

In contrast, the design of microbial fuel cells are much more challenging as it requires the development of a conductive matrix in conditions where the targeted organisms maintain their activity. As far as living cells are concerned, two options are being studied: (i) hydrogenproducing species, mainly cyanobacteria and micro-algae and (ii) electroactive organisms, especially bacteria [56]. The first approach has the main advantage that these organisms survive in a rather large range of $\mathrm{pH}$, ionic strength or even temperature, enlarging the possible conditions for gel synthesis. Moreover, some of them possess a so-called exopolysaccharide (EPS) that constitute a convenient barrier to avoid detrimental interactions not only between the silica internal surface and the cell membrane but also with other solid additives that may be present to insure conductivity (Fig. 3) [57]. Finally, their viability has been shown to be preserved over months period in silica [58]. However they have two major drawbacks. First they are photosynthetic organisms that require access to visible light. This is 
in contradiction with the incorporation of conductive species that absorb strongly in this wavelength domain. Second, $\mathrm{H}_{2}$ itself should be converted into protons and electrons, requiring an additional component or compartment in the biofuel cell device. Therefore, at this time, only the first step of the process, i.e. hydrogen production by silica-immobilized photosynthetic organisms has been achieved [59]. Using Synechocystis sp. cyanobacteria, the production rate was found comparable for immobilized cells and cells in suspension after optimization of silica precursors and additives [60].

The second option, i.e. the use of electroactive bacteria, has opposite advantages and drawbacks. On the one hand, bacteria do not require light to survive and they can produce electrons, although some molecular shuttle may be necessary to transport charge to the electrode surface. On the other hand, they are more sensitive to physico-chemical conditions and lack the protective EPS coating. The earliest report in this area was based on the use of a sol-gel process to deposit a silica layer on a biofilm of Shewanella oneidensis bacteria formed on a conductive carbon surface [61]. However, a true tridimensional encapsulation was only achieved recently using silica-filled graphite felt [62]. The viability of immobilized Escherichia coli bacteria was preserved in the sol-gel matrix (Fig. 4) and their electroactive metabolites could be used for current production using the conductive carbon network. Noticeably, the formation of silica-CNT materials in cytocompatible conditions, i.e. using an alcohol-free process at $\mathrm{pH}$ 7, was also reported, that appear promising for this application [63].

\section{Bio-hybrid materials for environment monitoring and remediation}

Silica gel presents great thermal stability and high surface area that contains many hydroxyl reactive groups. These groups provide adequate biding sites for the attachment of different organic compounds, so that silica gel surface can be easily functionalized. Through 
these chemical modifications new hybrid materials with high selectivity to retain pollutant compounds can be obtained that are currently evaluated in natural water treatment. For instance, 4-amino-2-mercaptopyrimidine was recently chosen for anchorage onto the silica surface due to the biding potential by amine and thiol groups for $\mathrm{Cu}(\mathrm{II})$ sorption [64]. Silica gels modified with EDTA and DTPA were investigated to remove $\mathrm{Co}(\mathrm{II})$ and $\mathrm{Ni}(\mathrm{II})$ from polluted water [65]. Some aliphatic amines were also immobilized onto silica gel to test their capacity to eliminate $\mathrm{Cu}(\mathrm{II})$ and $\mathrm{Fe}(\mathrm{III})$ from natural waters [66]. A great deal of papers describing Hg(II) removal from hybrid mesoporous materials are available [67,68]. More simply, N-pyrazole could be anchored on a silica gel surface for mercury elimination [69]. A green chemistry route to efficient $\mathrm{Hg}(\mathrm{II})$ sorbent was also described using gels obtained from natural silica functionalized with the amino acid L-cysteine [70]. In parallel, some natural products such as tannins were also immobilized over silica beads in order to enhance the material capacity to remove $\operatorname{Cr}(\mathrm{III})$ from aqueous solution [71]. Moreover, some current researches are based on the addition of some inorganic compounds to the sol-gel host in order to obtain composites materials with improved capacities for pollutant removal. For instance, hydroxyapatite, a good example of porous material with high metal affinity, has been associated with zirconia, leading to materials that combine affinity for cations and anions (Fig. 5) [72].

In contrast, there are only a few works concerning the sol-gel encapsulation technology applied to bioremediation processes. In enzymatic-based process, an interesting example is provided by an immobilized recombinant dye-decolorizing peroxidase [73]. This enzyme exhibits a very specific tertiary structure that could not be preserved by any traditional immobilization techniques, except for its adsorption in mesoporous silica. Regarding cell immobilization processes, some reports exist about the use of dead biomass either adsorbed on or trapped in silica [74,75]. Considering living organisms, microbial mats were 
immobilized on silica gel. The resulting silica mats particles were used for the bioremediation and bioreduction of uranium-contaminated waters [76]. Some sol-gel matrices have been functionalized with bacteria such as Bacillus sphaericus JG-A12 for the successful biosorption of uranium and copper [77]. Burkholderia sp and Stereum hirsutum have been trapped in silica gels for chromium and malachite green removal, respectively [78,79]. Nostoc calcicola immobilized in silica-coated alginate beads were shown to have high metal accumulation properties, the silica coating enhancing the stability of the beads upon recycling [80]. Yeast cells were immobilized in zirconia for 4-chloro-2-methylphenoxyacetic acid degradation but the viability rate of encapsulated cells was very poor [81]. Inorganic hosts prepared by the freeze-drying technique were shown to be suitable for Rhodococcus ruber immobilization and phenol degradation. These materials are promising but they are macroporous and allow internal cell division so that clogging and leaching can be expected on the long-term $[82,83]$.

The capture and degradation or conversion of green house gases (GHG) and volatile organic compounds (VOC) using sol-gel based materials is another area of intensive research $[84,85]$. For instance, several porous materials incorporating aminated molecules were evaluated for $\mathrm{CO}_{2}$ sorption and storage [86,87]. A promising alternative relies on the use of immobilized carbonic anhydrase enzymes [88]. Interestingly, Favre et al. showed that the pH modification induced by the enzymatic conversion of $\mathrm{CO}_{2}$ could be used to activate the gelation of silica precursor solutions [89]. Indeed entrapped photosynthetic organisms may in principle also be used for $\mathrm{CO}_{2}$ transformation into useful products, such as biofuels, [58] but the possibility to develop sol-gel based photobioreactors with long-term stability and on a large scale is still to be demonstrated.

Noticeably, a material that interacts with pollutants should in principle be also used as a sensor provided that the corresponding binding and/or transformation event is associated with 
a measurable signal. For instance, mesoporous silica materials modified with metal ligand and/or dyes combine the ability to simultaneously trap and detect heavy metals [90,91]. In the case of biohybrid materials, polysaccharides can indeed be used for sorption purposes but are hardly capable of transduction [92]. In contrast, many enzymes are able to transform organic pollutants, a reaction that can be detected by UV-visible absorption, fluorescence spectroscopy and electrochemical methods [93]. In this context, a biosensor based on the coencapsulation of urease and acetylcholinesterase (AChE) in the presence of a fluorescent dye in silica gels was described. Whereas AChE was useful for $\mathrm{pH}$ monitoring, the inhibition of urease activity by metal ions could be used for their detection and quantification [94]. Cellbased biosensors involving the sol-gel technology have also been described [95]. In a simple approach, the metal depletion of solutions in contact with silica gels containing dead algae can be followed by electrochemical measurements [96]. Considering living cells, most sensors are based on the use of photosynthetic organisms [97]. Modification of chlorophyll fluorescence or photosynthesis yield using the pulse amplitude modulated (PAM) fluorimetry technique can be used to directly monitor the impact of pollutants on cell behavior allowing the development of fiber-optic based biosensors [98,99]. Raman spectroscopy was also recently found useful to image the influence of toxic species on the production of carotenoid pigments (Fig. 6) [57]. Recently, hybrid materials consisting of algae-containing alginate beads trapped in a silica matrix were found suitable for the detection of the atrazine herbicide [100]. Such an approach is all the more interesting as previous works demonstrate both the possibility to tailor the silica gel optical properties to optimize algae survival [101] and the ability of the alginate network to be involved in the metal binding [80,102].

\section{Perspectives}


The examples provided in this short review illustrate the benefits of the sol-gel process in terms of designing more robust and complex (in terms of composition, structure and properties) materials than their bio/organic counterparts through a large diversity of processes.

Considering the environmental impact of sol-gel chemistry, one should emphasize that, although metal alkoxides cannot be considered as "green chemicals" due to their harsh conditions of preparation and associated alcohol content, the main advantage of the soft chemistry approach relies in low temperature/low pressure conditions that are a source of significant energy saving compared to the traditional ceramic technology. As far as the resulting materials are concerned, silica is certainly a specific case because of its intrinsicallybenign ecological impact. Other metal oxides that are currently often prepared by the sol-gel process, such as $\mathrm{Al}_{2} \mathrm{O}_{3}, \mathrm{ZrO}_{2}, \mathrm{TiO}_{2}$ or $\mathrm{V}_{2} \mathrm{O}_{5}$, may raise more environmental concerns. Interestingly, while the ecological impact of manufactured oxides is raising large interest from the point of view of living organisms (eco-toxicity), more efforts must be made to elucidate their life cycle, including biodegradation issues.

Another key advantage of the sol-gel process is the possibility to convert liquid systems into solids, providing easily handled and recoverable materials while preserving the structure and reactivity of the immobilized objects. This can be useful for storage purposes or for transferring homogeneous reactions into heterogeneous ones, as already well-known in catalysis but also for developments in biotechnology. Hence there is still a great deal of efforts to be done to evaluate and optimize the association of inorganic precursors with industrial by-products or wastes as well as with biomolecules or living organisms.

Needless to say, the urgency of the situation is a strong driving force for novel technological developments that fully integrate sustainability issues. We hope that this short 
review demonstrates that the sol-gel technology will play a major role in this direction in the nearest future.

\section{Acknowledgments}

L. C. thanks University of A Coruña for funding her stay in Paris. T. C. acknowledges financial support from the PEPS «Biofilms Biocapteurs Biopiles pour une Ingénierie Environnementale » program of Centre National de la Recherche Scientifique. 


\section{References}

[1] Popescu F, Ionel I (2010) Anthropogenic air pollution sources, in : Air Quality. Kumar A, ed. Sciyo

[2] Smith KA, Searchinger TD (2012) GCB Bioenergy 4 : 479-484

[3] Baccile N, Thomas B, Babonneau F, Coradin T (2009) J Mater Chem 19 :8537-8559

[4] Klein LC (2012) Conventional energy sources and alternative energy sources and the role of sol-gel processing, in : Sol-gel processing for conventional and alternative energy. Aparicio M, Jitianu A, Klein LC, eds. Springer

[5] Sol-Gel Methods for Materials Processing: Focusing on Materials for Pollution Control. Water Purification, and Soil Remediation. Innocenzi P, Zub YL, Kessler VG, eds. Springer (2007)

[6] Mammeri F, Le Bourhis E, Rozes L, Sanchez C (2005) J Mater Chem 15 : 3787-3811

[7] Sanchez C, Belleville P, Popall M, Nicole L (2011) Chem Soc Rev 40 : 696-753

[8] Gandini A (2011) Green Chem 13: 1061-1083

[9] Narayan R (2011) MRS Bulletin 36: 716 - 721

[10] Nanocomposites with biodegradable polymers. Mittal V, ed. Oxford University Press (2011)

[11] Agoudjil N, Sicard C, Jaouen V, Garnier C, Bonnin E, Steunou N, Coradin T (2012) Pure Appl Chem 84:2521-2529

[12] Shchipunov YA, Karpenko TY (2004) Langmuir 20: 3882-3887

[13] Boissiere M, Tourrette A, Devoisselle JM, Di Renzo F, Quignard F (2006) J Colloid Interface Sci 294: 109-116

[14] Singh V, Tiwari A, Pandey S, Singh SK, Sanghi R (2007) J Appl Polym Sci 104: 536544

[15] Yang Y, Coradin T (2008) Green Chem 10:183-190 
[16] Pinto RJB, Marques P, Barros-Timmons AM, Trindade T, Neto CP (2008) Composite Sci Technol 68: 1088-1093

[17] Litschauer M, Neouze MA, Haimer E, Henniges U, Potthast A, Rosenau T, Liebner F (2011) Cellulose 18: 143-149

[18] Maeda H, Nakajima M, Hagiwara T, Sawaguchi T, Yano S. (2006) J Mater Sci 41: $5646-5656$

[19] Yano S, Maeda H, Nakajima M, Hagiwara T, Sawaguchi T (2008) Cellulose 15: 111120

[20] Barud HS, Assuncao RMN, Martines MAU, Dexpert-Ghys J, Marques RFC, Messaddeq Y, Ribeiro SJL (2008) J Sol-Gel Sci Technol 46: 363-367

[21] Ashori A, Sheykhnazari S, Tabarsa T, Shakeri A, Golalipour M (2012) Carbohydrate Polym 90: 413-418.

[22] Zoppi RA, Goncalves MC (2002) J Appl Polym Sci 84: 2196-2205

[23] Benmouhoub N, Simmonet N, Agoudjil N, Coradin T (2008) Green Chem 10:957-964

[24] Liu BJ, Wang ZH, He JX (2012) Mater Lett 67: 8-10.

[25] Retuert J, Nunez A, Martinez F, Yazdani Pedram M (1997) Macromol Rapid Commun 18: $163-167$

[26] Smitha S, Shajesh P, Mukundan P, Warrier KGK (2008) J Mater Res 23: 2053-2060

[27] Liu YL, Su YH, Lai JY (2004) Polymer 45: 6831-6837

[28] Molvinger K, Quignard F, Brunel D, Boissiere M, Devoisselle JM (2004) Chem Mater 16: 3367-3372.

[29] Lan WJ, Li SW, Xu JH, Luo GS (2010) Biomed Microdevices 12: 1087-1095

[30] Shchipunov YA, Karpenko TY, Krekoten AV, Postnova IV (2005) J Colloid Interface Sci 287: 373-378

[31] Ayers MR, Hunt AJ (2001) J Non-Cryst Solids 285: 123-127 
[32] El Kadib A, Bousmina M (2012) Chem-Eur J 18: 8264-8277

[33] Tan XC, Tian YX, Cai, PX, Zou XY (2005) Anal Bioanal Chem 381: 500-507

[34] Li WJ, Yuan R, Chai YQ, Zhou L, Chen SH, Li N (2008) J Biochem Biophys Methods 70: 830-837

[35] Copello GJ, Mebert AM, Raineri M, Pesenti MP, Diaz LE (2011) J Hazard Mater 186: 932-939

[36] Repo E, Warchol JK, Bhatnagar A, Sillanpaa M (2011) J Colloid Interface Sci 358: $261-267$

[37] Shirosaki Y, Tsuru K, Hayakawa S, Osaka A, Lopes MA, Santos JD, Fernandes MH (2005) Biomaterials 26: 485-493

[38] Shirosaki Y, Tsuru K, Hayakawa S, Osaka A, Lopes MA, Santos JD, Costa MA, Fernandes MH (2009) Acta Biomater 5: 346-355

[39] Lee EJ, Shin DS, Kim HE, Kim HW, Koh YH, Jang JH (2009) Biomaterials 30: 743750

[40] Toskas G, Cherif C, Hund RD, Laourine E, Mahltig B, Fahmi A, Heinemann C, Hanke T (2013) Carbohydrate Polym 94: 713-722

[41] Bruce PG, Scrosati B, Tarascon JM (2008) Angew Chem Int Ed 47 : 2930-2946

[42] Brezesinski T, Wang J, Tolbert S, Dunn B (2010) Nature Materials 9 : 146-151

[43] Neyshadt S, Jahnke JP, Messinger RJ, Rawal A, Segal Peretz T, Huppert DH, Chmelka BF, Frey GL (2011) J Am Chem Soc 133 : 10119-10133

[44] Müller G, Boissière C, Grosso D, Ringuede A, Laberty-Robert C, Sanchez C (2012) J Mater Chem 22 : 9368-9373

[45] Laberty-Robert C, Vallé K, Pereira F, Sanchez C (2011) Chem Soc Rev 40 : 961-1005

[46] Lin B, Cheng S, Qiu L, Yan F, Shang S, Lu J (2010) Chem Mater 22 : 1807-1813

[47] Yang XY, Tian G, Jiang N, Su BL (2012) Energy Environ Sci 5 :5540-5563 
[48] Avnir D, Braun S, Lev O, Ottolenghi M (1994) Chem Mater 6: 1605-1614

[49] Carturan G, Campostrini R, Dire S, Scardi V, de Alteris E (1989) J Mol Catal 57: L13L16

[50] Avnir D, Coradin T, Lev O, Livage J (2006) J Mater Chem 16: 1013-1030

[51] Blondeau M, Coradin T (2012) J Mater Chem 22: 22335-22343

[52] Walcarius A (1999) Electroanal 10:1217-1235

[53] Wang Z, Etienne M, Pöller S, Schuhmann W, Kohring GW, Mamane V, Walcarius A (2012) Electroanal 24: 376-385

[54] Lim J, Malati P, Bonet F, Dunn B (2007) J Electrochem Soc 154:A140-A145

[55] Liu C, Alwarappan S, Chen Z, Kong X, Li CZ (2010) Biosens Bioelectron 15:18291833

[56] Logan BE, Rabaey K (2012) Science 337:686-690

[57] Sicard C, Brayner R, Margueritat J, Hémadi M, Couté A, Yéprémian C, Aubard J, Fiévet F, Livage J, Coradin T (2010) J Mater Chem 20: 9342-9347

[58] Leonard A, Rooke JC, Meunier CF, Sarmento H, Descy JP, Su BL (2010) Energy Environ Sci 3: 370-377

[59] Dickson DJ, Ely RL (2013) Appl Microbiol Biotechnol 97:1809-1819

[60] Dickson DJ, Page CJ, Ely RL (2009) Int J Hydrog Energy 34:204-215

[61] Luckarift HR, Sizemore SR, Roy J, Lau C, Gupta G, Atanassov P, Johnson GR (2010) Chem Commun 46:6048-6050

[62] Le Ouay B, Coradin T, Laberty-Robert C (2013) J Mater Chem B 1:606-609

[63] Le Ouay B, Lau-Truong S, Flahaut E, Brayner R, Aubard J, Coradin T, LabertyRobert C (2012) J Phys Chem C 116: 11306-11314

[64] Pereira AS, Ferreira G, Caetano, Martines MAU, Padilha PM, Santos A, Castro GR (2010) J Hazard Mater 175: 399-403 
[65] Repo E, Kurniawan TA, Warchol JK, Sillanpaa MET (2009) J Hazard Mater 171: $1071-1080$

[66] Ahmed SA, Soliman EM (2013) J Environ Sci Health Part A-Toxic/Hazard Subst Environ Eng 48: 817-828

[67] Antochshuk V, Olkhovyk O, Jaroniec M, Park IS, Ryoo R (2003) Langmuir 19:30133034

[68] Pérez-Quintanilla D, del Hierro I, Fajardo M, Sierra I (2006) J Hazard Mater 134:245256.

[69] Radi S, Attayibat A, Ramdani A, Bacquet M (2008) Eur Polym J 44: 3163-3168

[70] Chaves MRM, Valsaraj KT, DeLaune RD, Gambrell RP, Buchler PM (2011) Environ Technol 32: 1615-1625

[71] Huan X, Liao X, Shi B (2010) J Hazard Mater 173: 33-39

[72] Achelhi K, Masse S, Laurent G, Roux C, Laghzizil A, Saoiabi A, Coradin T (2011) Langmuir 27: 15176-15184

[73] Shakeri M, Shoda M (2008) J Mol Catal B 54:42-49

[74] Mahan CA, Holcombe JA (1992) Anal Chem 64: 1933-1939

[75] Soltmann U, Matys S, Kieszig G, Pompe W, Böttcher H (2010) J Water Res Protec 2: $115-122$

[76] Bender J, Duff MC, Phillips P, Hill M (2000) Environ Sci Technol 34: 3235-3241.

[77] Raff J, Soltmann U, Matys S, Selenska-Pobell S, Bottcher H, Pompe W (2003) Chem Mater 15: 240-244

[78] Perullini M, Jobbagy M, Mouso N, Forchiassin F, Bilmes SA (2010) J Mater Chem 20: 6479-6483

[79] Alvarez GS, Foglia ML, Camporotondi DE, Tuttolomondo MV, Desimone MF, Diaz LE (2011) J Mater Chem 21: 6359-6364 
[80] Ramachandran S, Coradin T, Jain PK, Verma SK (2009) Silicon 1: 215-223

[81] Sannino F, Pirozzi D, Aronne A, Fanelli E, Spaccini R, Yousuf A, Pernice P (2010) Environ Sci Technol 44: 9476-9481

[82] Soltmann U, Nies B, Bottcher H (2011) Adv Eng Mater 13: B25-B31

[83] Pannier A, Mkandawire M, Soltmann U, Pompe W, Bottcher H (2012) Appl Microbiol Biotechnol 93: 1755-1767

[84] Figueroa JD, Fout T, Plasynski S, McIlvried H, Srivastava RD (2008) Int J Greenhouse Gas Control 2: 9-20

[85] Tseng TK, Lin YS, Chen YJ, Chu H (2010) Int J Mol Sci 11:2336-2361

[86] Xomeritakis G, Tsai CY, Jiang YB, Brinker CJ (2009) J Membran Sci 341: 30-36

[87] Chen C, Ahn WS (2011) Chem Engin J 166: 646-651

[88] Pierre AC (2012) ISRN Chem Engin 2012, Article ID 753687

[89] Favre N, Ahmad Y, Pierre AC (2011) J Sol-Gel Sci Technol 58:442-451

[90] Liu T, Li G, Zhang N, Chen Y (2012) J Hazard Mater 201-202:155-161

[91] He D, He X, Wang K, Zhao Y, Zhou Z (2013) Langmuir 29:5896-5904

[92] Carro L, Herrero R, Barriada JL, Sastre de Vicente ME (2009) J Chem Technol Biotechnol 84:1688-1696

[93] Khan AA, Alzohairy MA (2010) Res J Biol Sci 5: 565-575.

[94] Tsai HC, Doong RA (2005) Biosens Bioelectron 20 :1796-1804

[95] Campas M, Carpentier R, Rouillon R (2008) Biotechnol Adv 26 :370-378

[96] Darder M, Aranda P, Burgos-Asperilla L, Llobera A, Cadarso VJ, Fernández-Sánchez C, Ruiz-Hitzky E (2010) J Mater Chem 20:9362-9369

[97] Depagne C, Roux C, Coradin T (2011) Anal Bioanal Chem 400 :965-976

[98] Nguyen-Ngoc H, Tran-Minh C (2007) Anal Chim Acta 583:161-165 
[99] Pena-Vazquez E, Maneiro E, Perez-Conde C, Cruz Moreno-Bondi M, Costas P (2009) Biosens Bioelectron 24 :3538-3542

[100] Ferro Y, Perullini M, Jobbagy M, Bilmes SA, Durrieu C (2012) Sensors 12 :1687916891

[101] Sicard C, Perullini M, Spedalieri C, Coradin T, Brayner R, Livage J, Jobbagy M, Bilmes SA (2011) $23: 1374-1378$

[102] Perullini M, Amoura M, Jobbagy M, Roux C, Livage J, Coradin T, Bilmes SA (2011) J Mater Chem $21: 8026-8031$ 


\section{Figure captions}

Fig. 1 SEM images of bacterial cellulose membranes (left) and BC-silica (66wt.\%) composite (right). Reproduced from [20] with kind permission from Springer Science+Business Media.

Fig. 2 (a) Optical micrograph of $\mathrm{SiO}_{2} /$ carboxymethyl cellulose CMC solutions/gels with increasing silicate content showing the sol-to-gel transition. SEM images of freeze-dried solutions and gels obtained for $\mathrm{SiO}_{2}: \mathrm{CMC}=$ (b) $0 \mathrm{wt} \%$, (c) $2 \mathrm{wt} \%$, (d) $8 \mathrm{wt} \%$ and (e) $10 \mathrm{wt} \%$. Reproduced from [23] with permission from The Royal Society of Chemistry (RSC).

Fig. 3 SEM (a) and TEM (b) images of encapsulated Klebsormidium flaccidum algal cells trapped in a silica matrix. (scale bar $=2 \mu \mathrm{m}$ ). Reproduced by courtesy of C. Sicard.

Fig. 4 Time evolution of fluorescent E. coli bacteria in graphite-silica electrodes as monitored by fluorescent microscopy. (scale bar $=20 \mu \mathrm{m}$ ). Reproduced from [62] with permission from The Royal Society of Chemistry (RSC).

Fig. 5 Zirconia-hydroxyapatite nanocomposites combining anionic and cationic sorption properties.White arrows on TEM image (left) show apatite nanorods within the zirconia matrix. Reprinted with permission from [72], Copyright (2011), American Chemical Society.

Fig. 6 Raman imaging of encapsulated Klebsormidium flaccidum algal cells : reconstructed images from the intensity of Raman spectra with excitation at (a) $514 \mathrm{~nm}$ and (b) $633 \mathrm{~nm}$, and (c) corresponding optical microscopy image. Reproduced from [57] with permission from The Royal Society of Chemistry (RSC). 
Figure 1

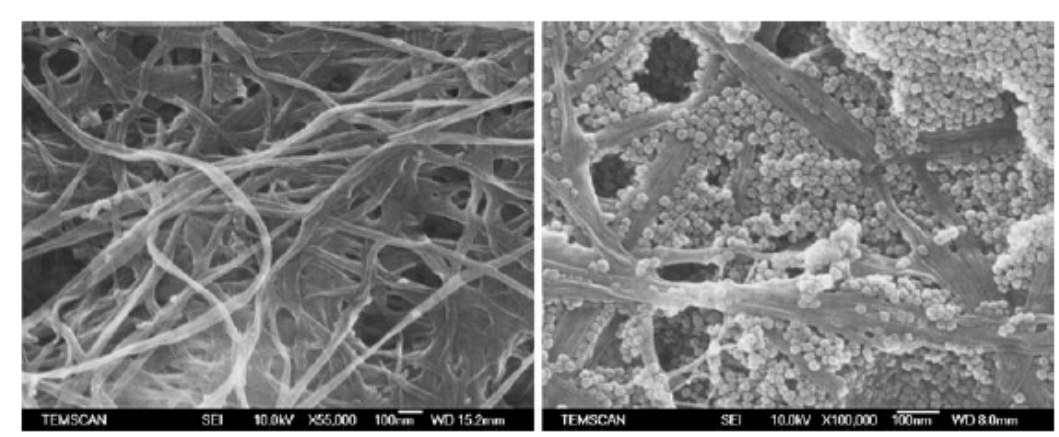


Figure 2

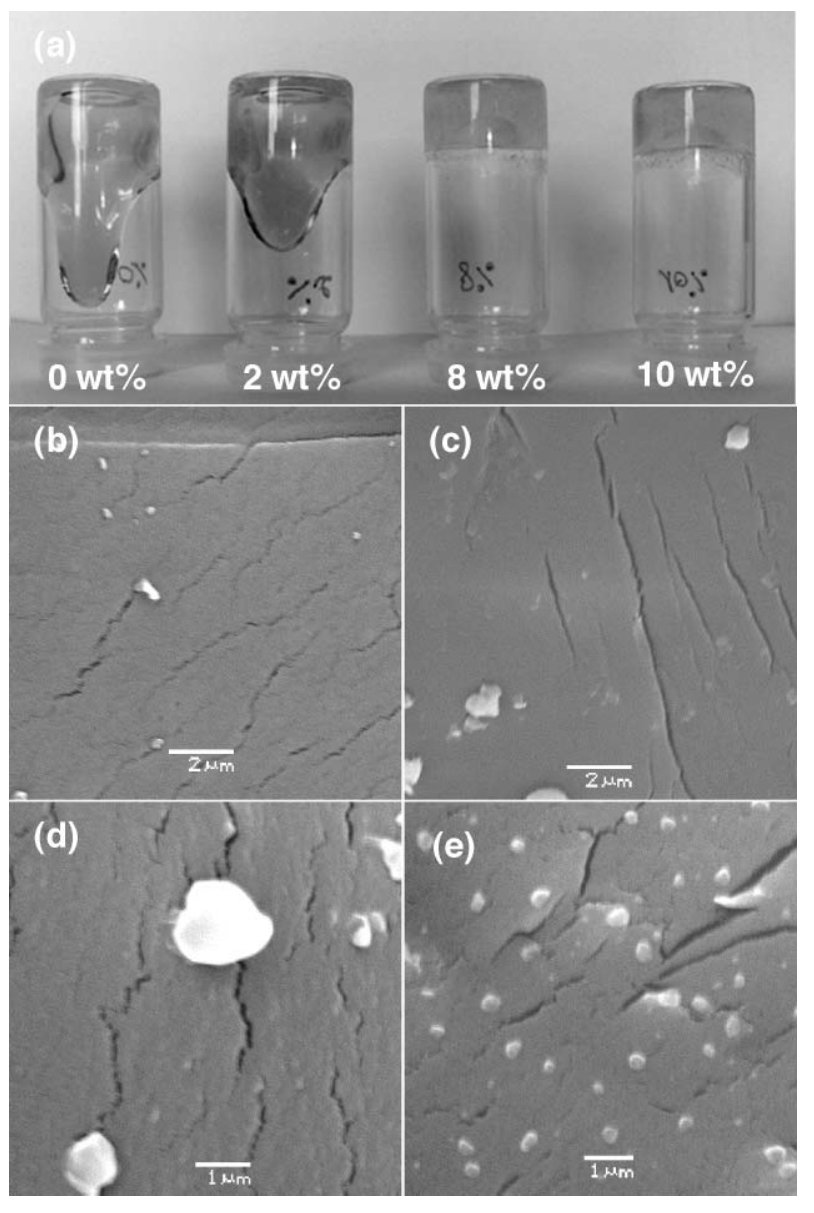


Figure 3

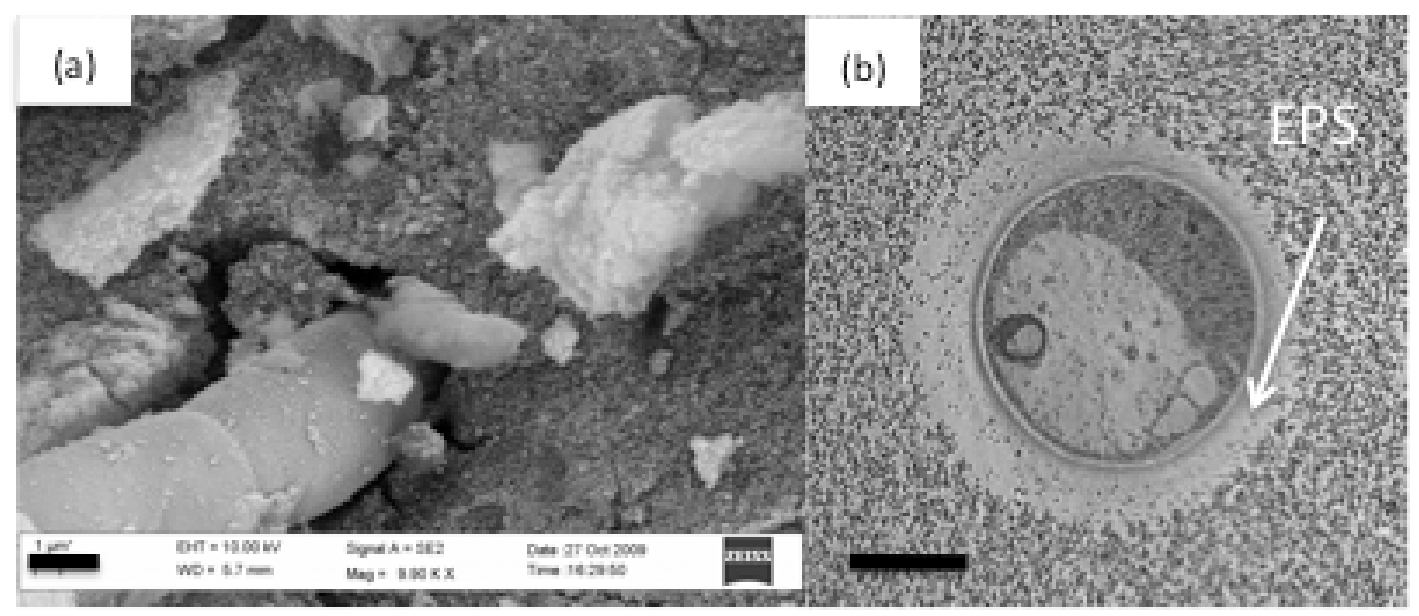


Figure 4

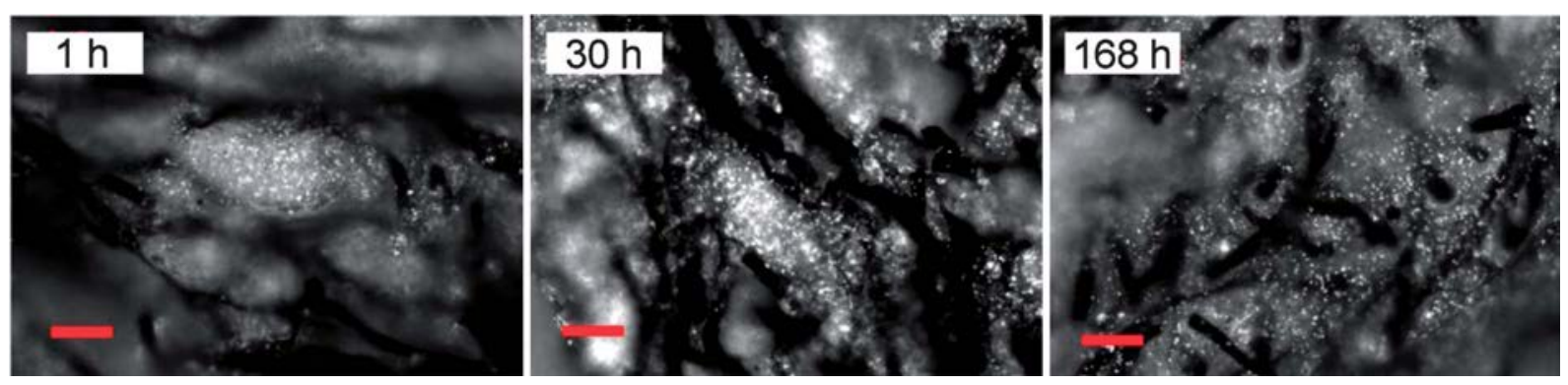


Figure 5

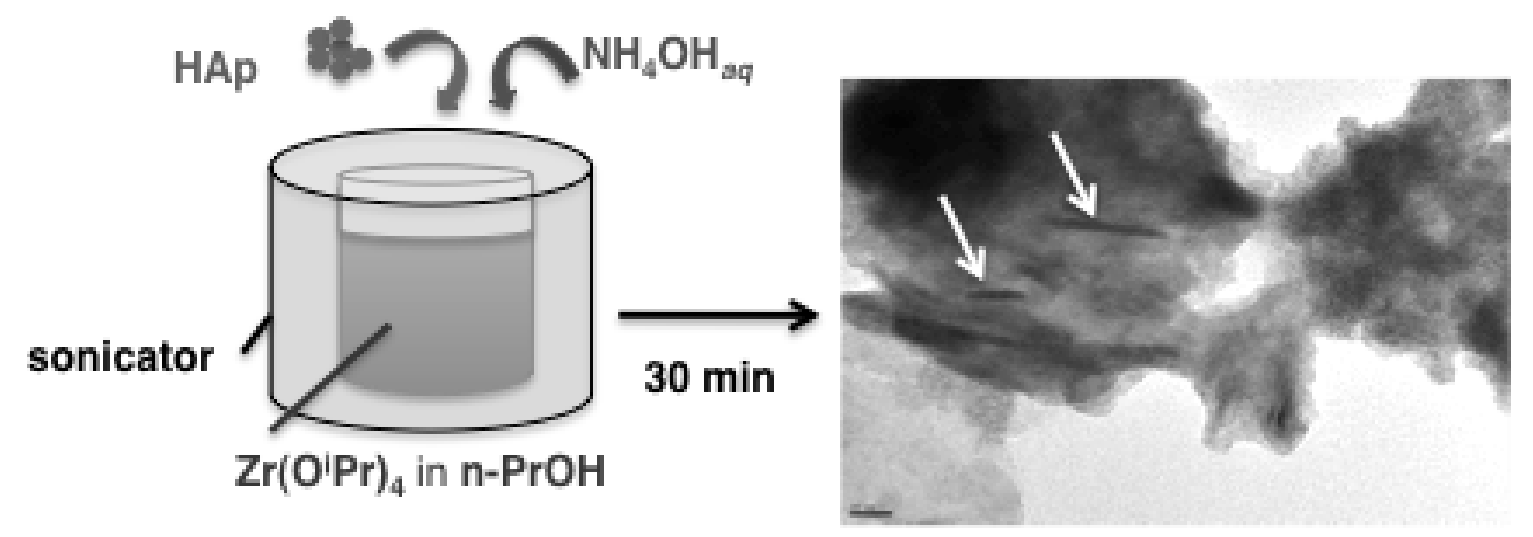


Figure 6

(a)

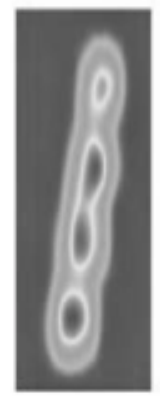

(b)

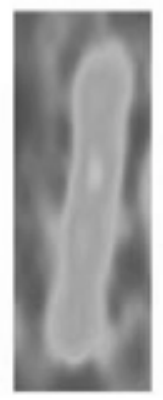

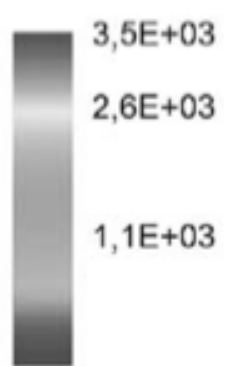

(c)

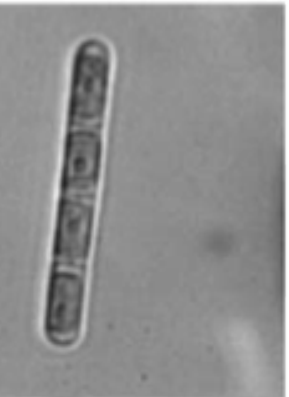

